\title{
Editorial: Celebrating Thirty-Five Years of Publication
}

\author{
ELAINE ASTON
}

This issue celebrates thirty-five years of TRI (New Series) publication, from the first issue in October 1975 through to this October 2010 edition. Last year, Cambridge Journals launched the digitized TRI archive, housing all of the volumes from the inaugural 1975 issue through to Volume 25 in 2000. During those first twenty-five years of now digitized publication, Oxford University Press served as the journal's home under the editorship of Claude Schumacher. It was in 2001 that the journal moved across to Cambridge with Brian Singleton as its Senior Editor.

TRI's Cambridge years with Brian Singleton (2001-3), followed by Christopher Balme (2004-6), and then Freddie Rokem (2007-9) open this special issue in a three-part retrospective. Between them, they tell the 'story' of the journal, detail the 'performance' history of TRI in both the academic and the business sense. As a retrospective, this threeway contribution reminds of some of the particular concerns, concepts, or issues that have come to occupy the field of theatre and performance studies - the latter a conjugation which in and of itself has been at the centre of much, often heated, debate as their article discusses. This, and various gender 'troubles', questions of the intercultural kind, or understandings of postdramatic theatre and the conversations between philosophy and theatre, are reflected upon in their memoir.

To think back through TRI histories is understandably to think also of Federation histories: of the synergies generated by the journal's association with the International Federation for Theatre Research/La Fédération internationale pour la recherche théâtrale (IFTR/FIRT). Never the 'mouthpiece' of the organization, as Christopher Balme explains, the journal nonetheless benefits from the Federation - not least, for instance, in the way that a good percentage of articles submitted to the peer-reviewing, publications process come from IFTR/FIRT members. I would go further to argue that one of the very real research strengths of the organization and potentially, therefore, for TRI resides in its working groups. To acknowledge, celebrate and make visible some of the ways in which theatre and performance studies benefit from the international research networks fostered by the Federation's groups, I invited two of them to contribute to this special issue: the Theatre Historiography and Arabic Theatre Working Groups.

Thomas Postlewait and Barbara Sušec Michieli, co-authors of 'A Transnational Community of Scholars: The Theatre Historiography Working Group in IFTR/FIRT', collaborate on writing the history of the group, the founding of which was influenced by the 1989 IFTR Stockholm conference. This seminal conference event, organized by 
Willmar Sauter, seeded the idea for working groups through the initiative Sauter took to organize contributions into small, topic-based, group discussions, rather than big, public panels of papers. (Anyone who has been a member of a working group instantly will recognize this as an enduring blueprint.) The Performance Analysis Working Group was the first group to be officially constituted, closely followed by Theatre Historiography. In their expertly traced histories of the group's work, Postlewait and Sušec Michieli are at pains to point out the particular advantages to theatre research advanced through being a member of a community: 'as historians we may do research alone, but we think and write within a community of scholars'. And as a research community, a Federation working group also benefits from its international composition, from the possibilities that accrue from thinking theatre scholarship in an international mix of competing ideas, views, theories, perspectives and what these might be able to 'do' differently to 'home-alone' studies.

While Theatre Historiography ranks as the second-oldest working group, the Arabic Theatre Working Group is much younger. Formed in 2006, the group is a response to the hitherto chronic scholarly neglect of Arabic theatre in studies of international theatre. As authors Khalid Amine, Hazem Azmy and Marvin Carlson explain at the outset of their article, so very little has shifted over the years in terms of the Western (European and American) bias of theatre research. Contesting this bias, the group gives an account of their directions, subjects, and bricoleur methodologies. Presenting these and other matters, the authors provide a seminal survey - one that I trust will, in future years, serve as a key point of reference for scholars looking to familiarize themselves with Arabic theatre research.

Joining these working-group contributions are two further sorties into history. Adrian Curtin's 'Cruel Vibrations: Sounding Out Antonin Artaud's Production of Les Cenci' is this year's winning essay in the IFTR/FIRT competition for new scholars. On behalf of the TRI board, I congratulate Adrian Curtin for his ambitious and innovative historiographical move to 'listen back' to the theatrical soundscape of Artaud's Les Cenci. In contrast to this detailed moment in European theatre history, Temple Hauptfleisch takes us back through five tipping points in the twentieth-century history of theatre studies in South Africa. Here too I hope that the scope and content of this article will serve as a kind of archival base for future research, given its densely rich noting of key publications, sources and resources for South African theatre.

Having opened this issue with retrospective reflections on TRI and the field of theatre and performance studies, this issue closes with a prospective Critical Futures Forum. For this, contributors from different geographies and theatre cultures were invited to put forward their views on current and future research directions, trends or urgent issues. Concluding this editorial note, I would add my own voice to those in the forum, by briefly noting the 'critical futures' role for TRI as it continues to create a publishing space for international theatre research.

In this regard it is the idea of the federal that underpins IFTR/FIRT that I see in future terms as critical to the journal's work. By this I mean the ongoing endeavours of the journal to strategize for 'states' of international theatre research that are not governed by the primacy of Western theories and performance practices, but by an agreement to 
recognize 'differing world contexts' and their 'diversity of critical idioms'. At its core, as previous TRI editors attest, this involves reaching beyond anglophone-dominated theatre 'territories'. Yet to state this is perhaps to belie the complex negotiations this aspiration involves. For the postcolonial bricoleur which Amine, Azmy and Carlson describe, it can entail the difficult question of what critical tools to pick up to analyse a local theatre form or practice for an international journal readership. Viewed from the other (editorial) side, the task of then balancing the academic writing needs of the (English) journal with a federal remit is far from easy; it can feel like a discomforting act of colonial gazing and/or intervention. Nonetheless I am hopeful, given the encouraging signs of national and linguistic collaborations evidenced in this issue and the opportunities created for collaboration in our new dossier and project submissions, of productive, progressive academic border crossings now and in the future.

To conceive of international, federal 'states' of theatre research is also to think non-hierarchically about a critical landscape of ideas, theories, critical practices and methodologies. In this regard, the 'critical futures' of TRI have an ongoing need to be of heterogeneous rather than homogeneous scope, to invest in a plurality of ideas and practices rather than to endorse a particular specialist approach or line of enquiry.

In brief, theatre conceived of as a federal system of international research faces a number of challenges, risks and difficulties, but, nonetheless, is a concept critical to achieving a less mainstream Euro-American repertoire of theatre and performance ideas, forms, traditions and practices. 